\title{
Physical and chemical composition of soil collected from different habitats of Dumbi Inselberg in Zaria, Northern Guinea savanna, Nigeria
}

\author{
Tanko, D. \\ Department of Biological Sciences, Federal University Lokoja, Kogi State, Nigeria.
}

Accepted 13 July, 2018

\begin{abstract}
For effectively functioning ecosystems, soil conservation in the means of physical and chemical properties is essential. Granite ecosystems have not received much attention in research and therefore, this study was carried out at an inselberg in Zaria in Nigeria. In the scope of this research, soils samples were collected at four locations (farmed lands, windward side, leeward side and the top of the inselberg) at depths 0 to $15 \mathrm{~cm}$, 15 to $30 \mathrm{~cm}$ and 30 to $45 \mathrm{~cm}$. The samples were analyzed for soil textural class, $\mathrm{pH}$ value, Organic Carbon and Exchangeable Cations. The study revealed higher percentage of clay and silt (28.93 and $12.90 \%$ respectively) in the windward samples which differed significantly $(p<0.05)$ with the other samples. Increase in clay contents with depth was statistically significant $(p<0.05)$. Silt in windward, leeward and inselberg did not differ significantly $(p>0.05)$, however the 3 samples differ significantly $(p<0.05)$ with the farmland. Sand distribution showed significant $(P<0.05)$ decrease with depth. The windward and cultivated soil samples had sand-clay-loam soil while the leeward and the rock outcrop had sandy-loamy soil. The soil $\mathrm{pH}$ ranged between 5.4 and 6.0 in all the samples. The $\mathrm{pH}$ in the cultivated plot differed significantly $(\mathrm{P}<$ $0.05)$ with the other 3 plots. The Organic Carbon (OC) was moderate $\left(10.58 \mathrm{~kg}^{-1}\right)$ in the leeward plot very low $\left(<10 \mathrm{gkg}^{-1}\right)$ in the other plots. $O C$ showed a significant $(P<0.05)$ decrease with depth. Exchangeable Magnesium differed significantly $(p<0.05)$ with depths but not with plots. The higher acidic reaction of cultivated soil compared to the other plots was probably caused by the use of inorganic fertilizer during crop farming. The medium soil organic content at the top soil was expected because organic debris often accumulated at the top soil. Significant increase in magnesium with depth was probably due to leaching. The soil characteristics of the study site revealed the nutrients level to be lower than expected of a forest outlier, rather, it correspond with other soils of the savanna wood land. This is an indication that inselberg's habitats are currently witnessing degradation. Further studies on other inselbergs are hereby recommended.
\end{abstract}

Keywords: Soil, inselbergs, conservation, ecosystem, physical and chemical parameters, organic contents.

E-mail: tyankwa2007@yahoo.com. Tel: 07039137101.

\section{INTRODUCTION}

The conservation and proper management of soil organic matter is essential to soil functions in any ecosystem. This is because soil organic matter provides services, which can be described both as soil fertility and environmental functions from the perspective of farmers and the society respectively (Feller et al., 2001). Appropriate management of soil organic matter ensures soil fertility and minimizes agricultural impact on the environment through carbon sequestration, ensure erosion control and preservation of soil biodiversity (Six et al., 2002). Soil organic carbon is known to have a direct relationship with Electrical conductivity, $\mathrm{pH}$, Cation exchange capacity and phosphorus (Fagwalawa et al., 2014). 
Land degradation and the effects of soil organic matter loss are particularly critical in arid, semi-arid and subhumid areas of the tropical regions, where the risk of desertification is great. Reduction in precipitation and increase in temperature associated with global warming will further undermine the integrity of these ecosystems. One possible effect of global warming will be to accelerate soil organic matter decomposition thereby, releasing carbon-dioxide $\left(\mathrm{CO}_{2}\right)$ to the atmosphere, which will further enhance the glasshouse effect (Jenkinson et al., 1991).

Land use and land use changes are widely recognized as the key drivers of the global carbon dynamics. Good and appropriate land use practices have the ability to substantially reduce potential carbon sink in soils. In the past, farmers in dryland ecologies maintained equilibrium with the agroforestry systems of farming (Ganry et al., 2001). However, increased radiative forces arising from anthropogenic emission of gases to the atmosphere, along with population increases and reduced fallow periods upset the balance of the soil physical and chemical characterisitics. Land use such as afforestation, reforestation, grazing and conversion of natural to managed ecosystem alters the availability of organic matter inside the soil in both possible ways, by building up and decomposition. Organic matter apart from their nutrient content also has the effects of improving soil texture, aeration, water retention capacity and to regulate soil temperature (Uwah et al., 2012)

Sustainable management and restoration of degraded soils is necessary in order to reverse the negative effects and to protect terrestrial ecosystems. Afforestation of degraded land can potentially enhance carbon sequestration (Johnson, 1992).

The Nigerian Guinea Savanna is currently witnessing increasing intensities of crop and livestock production. Nomads and semi-nomads raise livestock by employing a free grazing feeding pattern (Odunze et al., 2004). This free grazing pattern was very obvious during the study. International Livestock Research Institute, ILRI (1997) and Odunze et al. (1996) reported that this over-grazing, has its attendant problems such as enhanced soil erosion, de-vegetation of the land area and desert encroachment. Crop production in the zone involves ploughing, harrowing and ridging. This is done with no special attention to conservation measures against soil nutrient depletion, soil erosion or runoff. Inselbergs in the past were considered waste lands because of the difficulty in ploughing the soil. Today, increasing cost and erratic availability of mineral fertilizer limits farmers' capacity to access to sufficient and appropriate fertilizer for crop production (ILRI, 1997; Longtau et al., 2002). This alongside population drastic increased has led farmers to explore lands initially considered waste. In recent times human activities became obvious at inselbergs. With the exploration of inselbergs by humans, this granite has always been given less attention in scientific studies especially the aspect of soil ecology (Tanko, 2012).

Odunze (2003) opined that the soils in the Northern Guinea Savanna have dominantly Kaolite clays and are sandy to sandy-loam in texture. They have low available soil moisture retention capacity and encourage leaching of nutrients away from the rooting depth of most crops. The soils therefore become degraded due to effects of soil erosion, deforestation, overgrazing, nutrient mining and poor soil management strategies applied by farmers. This study therefore aimed at the bridging gap in the knowledge of soil ecology of Inselbergs in the Nigerian Guinea savanna.

\section{MATERIALS AND METHODS}

\section{Study site}

Dumbi inselbergs are located near Dumbi village about 19 kilometers away from Zaria along the Zaria-Kaduna highway. It is located on Longitude $07^{\circ} 39.21^{\prime} \mathrm{E}$ to $07^{\circ} 39.23^{\prime} \mathrm{E}$ and Latitude $10^{\circ} 32^{\prime} 54^{\prime \prime} \mathrm{N}$ to $10^{\circ} 56^{\prime} .98^{\prime \prime} \mathrm{N}$ and has an altitude of $756.82 \mathrm{~m}$ above sea level and $111.56 \mathrm{~m}$ above the surrounding area. The area has two major seasons, the dry season which usually starts in October and lasts till early April and the rainy season which commences from late April and ends in October.

The area normally experiences Harmattan during the dry season which starts in December to late February when the lowest annual temperature of $25.6^{\circ} \mathrm{C}$ is recorded. Shortly after the Harmattan is a period of extreme heat which lasts for about 2 months and that is the period during which the highest annual temperatures of $38^{\circ} \mathrm{C}$ was recorded.

\section{Determination of the mineral composition of the soil}

A total of 16 soil samples were collected at four locations with a soil auger at depths 0 to $15 \mathrm{~cm}, 15$ to $30 \mathrm{~cm}$ and 30 to $45 \mathrm{~cm}$ depth at both the unfarmed windward, unfarmed leeward and the cultivated plots along two diagonals of the study plot. However, soil from the Inselbergs was taken from 0 to $15 \mathrm{~cm}$ and 15 to $30 \mathrm{~cm}$ depth only because the soil on the Inselbergs was usually not up to $45 \mathrm{~cm}$ deep. Location 1 comprised soil in the windward side of the main rock outcrop, the second location was soil from the leeward side of the main rock outcrop, the third location was soil that had collected on the rock surface and the forth location was soil from a cultivated land adjacent to the main rock outcrop. Soil samples were homogenized, air dried, ground and sieved through $2.0 \mathrm{~mm}$ sieve to obtain subsamples less than $2.0 \mathrm{~mm}$ in diameter (Smart, 2012). The smaller than $2 \mathrm{~mm}$ fractions were used for soil $\mathrm{pH}$, particle size distribution, cation exchange capacity, exchangeable bases and exchangeable acidity determination.

\section{Analytical procedures}

Analytical procedures are given in Table 1.

\section{Statistical analysis}

Data obtained were subjected to Analysis of Variance (ANOVA) using the General Linear Model procedure of SAS 9.3 software (SAS, 2011). Differences between means were separated using 
Table 1. Analytical procedures.

\begin{tabular}{|c|c|}
\hline Physical and chemical parameters & Techniques/procedures used \\
\hline Particle size distribution & $\begin{array}{l}\text { Bouyoucos hydrometer method (Gee and Bauder, 1986; Jackson and Raw 1996). } \\
\text { Where core samples could not be obtained, clod method of Blake (1965) was used }\end{array}$ \\
\hline Textural classes & These were obtained from textural triangle using USDA (1975) approach. \\
\hline Soil pH & $\begin{array}{l}\mathrm{pH} \text { meter techniques by Day (1965) and Bates (1954). This was done by dipping the } \\
\mathrm{pH} \text { meter in water and } 0.01 \mathrm{M} \mathrm{CaCl}_{2}\end{array}$ \\
\hline Electrical conductivity & pH meter technique by Day (1965) \\
\hline Soil organic carbon & $\begin{array}{l}\text { This was determined by dichromate oxidation method as described by Nelson and } \\
\text { Sommers (1982) }\end{array}$ \\
\hline Cation exchange capacity & $\begin{array}{l}\text { Exchangeable Cation were extracted with } 1 \mathrm{~N} \mathrm{NH}{ }_{4} \text { OAc saturation method (Chapman, } \\
\text { 1965). }\end{array}$ \\
\hline Exchangeable Calcium and Magnesium & These were determined by EDTA titration method (Agbenin, 1995; Smart, 2012), \\
\hline Potassium and sodium & Determined using flame photometry (Anderson and Ingram, 1993). \\
\hline Exchangeable acidity & $\begin{array}{l}\text { Determined by shaking soil in } 0.01 \mathrm{M} \mathrm{KCl} \text { and filtrate was titrated with } 0.1 \mathrm{MNaOH} \\
\text { (Agbenin, 1995). }\end{array}$ \\
\hline Sodium Absorption Ratio, SAR & SAR $=$ Exchangeable $\left\{\mathrm{Na}^{+} / \sqrt{ } 1 / 2\left(\mathrm{Ca}^{2+} \mathrm{Mg}^{2+}\right)\right\}$ (Oster and Posito, 1980) \\
\hline Exchangeable Sodium Percentage, ESP & $\begin{array}{l}\mathrm{ESP}=\text { Exchangeable }\{\mathrm{Na} / \mathrm{Ca}+\mathrm{Mg}+\mathrm{K}+\mathrm{Na}\} \times 100 \\
\text { (Oster and Posito, } 1980)\end{array}$ \\
\hline
\end{tabular}

Duncan Multiple Range Test at 5\% level of probability.

\section{RESULTS}

\section{Physical and chemical characteristics of the soils}

\section{Particle size and textural class of soils}

There was higher percentage of clay $(28.93 \%)$ in the windward plot followed by the cultivated plot $(23.40 \%)$, while the soil on the rock outcrop had the least clay content. The high clay content in the windward plot differed significantly $(P<0.05)$ from the clay content of the leeward plot, rock outcrop plot and the plot in cultivated land. Clay content was seen to increase with depth from 0 to $45 \mathrm{~cm}$ and this variation in clay content between the depths was significantly different $(P<0.05)$ as shown in Table 1.

Silt content was also higher $(12.90 \%)$ in the windward plot and was least in the cultivated plot (3.61\%). The percentage silt in the windward, leeward and the rock outcrop plots did not differ significantly but there was significant difference $(P<0.05)$ between these three plots and the cultivated plot. Silt was higher in the top-soil (0 to $15 \mathrm{~cm}$ ) than in the sub-soil, but this difference was not significant $(P>0.05)$ as seen in Table 2 .

Percentage sand was higher in the cultivated plot $(72.99 \%)$ while the windward plot had the lowest $(58.17 \%)$ percentage sand. Percentage sand in the windward plot differed significantly $(P<0.05)$ from that of the leeward plot, rock outcrop and the plot in the cultivated farmland. Sand distribution in the soil profile showed that percentage sand decreased significantly $(P$ $<0.05)$ with increase in depth. Table 2 is the soil textural class.

The windward plot and the plot in the cultivated farmland had similar textural class (sandy-clay-loam), while the leeward and the rock outcrop both had sandyloam soils. With respect to depth, the top soil was sandyloam, while the sub-soil was sandy-clay.

\section{Chemical composition of the soils}

The $\mathrm{pH}$ of the soils ranged between 5.4 and 6.0 in all the four sample plots. The $\mathrm{pH}$ of the soil in the cultivated farmland differed significantly $(\mathrm{P}<0.05)$ from the soil $\mathrm{pH}$ 
Table 2. Distribution of particle size and textural class of the soils of the study site.

\begin{tabular}{lcccc}
\hline Treatments & $\begin{array}{c}\text { \%Clay } \\
\text { Mean } \pm \text { SE }\end{array}$ & $\begin{array}{c}\text { \%Silt } \\
\text { Mean } \pm \text { SE }\end{array}$ & $\begin{array}{c}\text { \%Sand } \\
\text { Mean } \pm \text { SE }\end{array}$ & $\begin{array}{l}\text { Textural class } \\
\text { USDA.NRCS (1992) }\end{array}$ \\
\hline Bulk soil & & & & \\
Windward site plot & $28.93 \pm 0.020^{\mathrm{A}}$ & $12.90 \pm 0.020^{\mathrm{A}}$ & $58.17 \pm 2.060^{\mathrm{B}}$ & Sandy Clay Loam \\
Leeward site plot & $20.11 \pm 0.020^{\mathrm{B}}$ & $10.95 \pm 0.030^{\mathrm{A}}$ & $68.94 \pm 2.520^{\mathrm{A}}$ & Sandy Loam \\
Rock outcrop plot & $19.68 \pm 0.030^{\mathrm{B}}$ & $8.37 \pm 0.040^{\mathrm{A}}$ & $71.95 \pm 3.090^{\mathrm{A}}$ & Sandy Loam \\
Cultivated farmland plot & $23.40 \pm 0.030^{\mathrm{B}}$ & $3.61 \pm 0.040^{\mathrm{B}}$ & $72.99 \pm 3.570^{\mathrm{A}}$ & Sandy Clay Loam \\
& & & & \\
Depths (cm) & & & & \\
$0-15$ & $13.37 \pm 0.020^{\mathrm{C}}$ & $22.24 \pm 0.020$ & $64.39 \pm 2.060$ & Sandy Loam \\
$15-30$ & $26.56 \pm 0.020^{\mathrm{B}}$ & $18.20 \pm 0.020$ & $55.24 \pm 2.060$ & Sandy Clay Loam \\
$30-45$ & $32.95 \pm 0.030^{\mathrm{A}}$ & $19.48 \pm 0.040$ & $47.58 \pm 3.090$ & Sandy Clay Loam \\
\hline
\end{tabular}

Means with the same superscripts along the vertical columns are not significantly different at $0.05 \%$ level.

of the windward, leeward and the rock outcrop but, did not differ significantly $(P>0.05)$ as soil depth increased. The soil $\mathrm{pH}\left(\mathrm{H}_{2} \mathrm{O}\right)$ had values of between 5.4 and 6.0, while $\mathrm{pH}\left(\mathrm{CaCl}_{2}\right)$ ranged between 4.8 and 5.1.

The organic carbon content was generally very low $\left(<10 \mathrm{gkg}^{-1}\right)$ in the windward, rock outcrop and the cultivated farmland plots but was moderate $\left(10.5 \mathrm{gkg}^{-1}\right)$ in the leeward plot. These differences in organic matter content between the plots were not significant $(P>0.05)$. The organic carbon decreased with increase in depth, 0 to $15 \mathrm{~cm}$ having a moderate organic content while 15 to $45 \mathrm{~cm}$ had lower organic carbon. The decrease in organic matter with depth was significant $(P<0.05)$ between plots.

Soil Electrical Conductivity did not differ with location. Electrical Conductivity of the four plots sampled indicated low salinity $\left(<4 \mathrm{dsm}^{-1}\right)$ and a similar trend was observed along the depths (Table 3). Exchangeable calcium content of the soil was high $\left(>5 \mathrm{cmol} 10 \mathrm{~kg}^{-1}\right)$ in the windward plot, but medium (2.94 to $3.32 \mathrm{cmol} 10 \mathrm{~kg}^{-1}$ ) in the other plots sampled, though the differences were not statistically significant $(P>0.05)$. The exchangeable calcium was generally not high at all the three soil depths. However, at depth 0 to $15 \mathrm{~cm}$ and 30 to $45 \mathrm{~cm}$ $\mathrm{Ca}$ values $\left(4.57\right.$ and $\left.4.23 \mathrm{cmol} 10 \mathrm{~kg}^{-1}\right)$ were higher than at depth 15 to $30 \mathrm{~cm}\left(2.76 \mathrm{cmol} 10 \mathrm{~kg}^{-1}\right)$, though not significant $(P>0.05)$.

Exchangeable Magnesium (Mg) was seen to be generally high $\left(>1 \mathrm{cmol} 10 \mathrm{~kg}^{-1}\right)$ in all the four sample plots. Exchangeable $\mathrm{Mg}$ was also generally high at all three depths categories, and significantly increased with increase in depth $(P<0.05)$.

Exchangeable Potassium (K) was generally moderate in all the four plots and the three depth categories sampled. Exchangeable $\mathrm{K}$ values appeared higher in the windward plot when compared to other locations, but this was not statistically significant $(P>0.05)$.

Exchangeable Sodium $(\mathrm{Na})$ in the soils ranged between 0.36 and $0.46 \mathrm{cmol} 10 \mathrm{~kg}^{-1}$ in the four plots sampled. This is within the range of high $\mathrm{Na}$ availability in soils. The Exchangeable $\mathrm{Na}$ was high at all the depth categories of the soil $\left(>0.3 \mathrm{cmol} 10 \mathrm{~kg}^{-1}\right)$. The detail of exchange cations is shown in Table 4.

Sodium Absorption Ratio (SAR), Exchangeable Sodium Percentage (ESP) and Exchangeable Acidity between the plots and within the soil depth did not differ significantly $(P>0.05)$. The ESP was seen to increase in depth as can be seen in Table 5.

\section{DISCUSSION}

\section{Soil chemical and physical composition}

\section{Soil reaction}

The comparatively higher acidic reaction of cultivated soil (plot 3 ) of the Dumbi inselberg compared to soil of leeward, windward and outcrops could have resulted from added amendments to provide nutrients for arable crops. A cultivated area usually receives soil amendments like inorganic and organic fertilizers during crop farming. Accumulation of these soil amendments may be the probable reason for low $\mathrm{pH}$ value. Iwuafor et al. (2006) reported that application of nitrogenous forms of inorganic fertilizer will lower $\mathrm{pH}$ and accelerate acidity in soils. The higher acidity in the cultivated plot suggests that the soils need to be amended to restore the $\mathrm{pH}$ values to a range between 5.6 and 7.3. Low $\mathrm{pH}$ in the cultivated plot may be due to low organic matter content. Organic matter helps to keep the $\mathrm{pH}$ higher (Fagawalawa et al., 2014). Smart (2012) also observed lower pH and Organic carbon in cultivated plot.

Soil $\mathrm{pH}$ values were generally moderately acidic throughout the profile $(0$ to $45 \mathrm{~cm})$. Such $\mathrm{pH}$ values were recommended by Odunze et al. (2004) as being conducive for plant growth especially in the northern Guinea savanna. 
Table 3. Chemical characteristics of soils in the Dumbi Inselbergs and their environs.

\begin{tabular}{|c|c|c|c|c|}
\hline \multirow[b]{2}{*}{ Treatments } & \multicolumn{2}{|c|}{ Soil pH } & \multirow{2}{*}{$\begin{array}{l}\text { Organic carbon }\left(\mathrm{g} \mathrm{kg}^{-1}\right) \\
\text { Mean } \pm \mathrm{SE}\end{array}$} & \multirow{2}{*}{$\begin{array}{l}\text { Electrical conductivity }\left(\mathrm{dsm}^{-1}\right) \\
\text { Mean } \pm \mathrm{SE}\end{array}$} \\
\hline & $\begin{array}{c}\mathrm{H}_{2} \mathrm{O} \\
\text { Mean } \pm \text { SE }\end{array}$ & $\begin{array}{c}\mathrm{CaCl}_{2} \\
\text { Mean } \pm \mathrm{SE}\end{array}$ & & \\
\hline \multicolumn{5}{|l|}{ Bulk soil } \\
\hline Plot on windward side & $5.98 \pm 0.003^{A}$ & $4.98 \pm 0.005$ & $8.9 \pm 0.006$ & $0.05 \pm 0.001$ \\
\hline Plot on leeward side & $5.96 \pm 0.004^{A}$ & $5.08 \pm 0.006$ & $10.5 \pm 0.007$ & $0.10 \pm 0.001$ \\
\hline Plot on the rock outcrop & $6.02 \pm 0.005^{A}$ & $5.10 \pm 0.07$ & $7.7 \pm 0.009$ & $0.06 \pm 0.001$ \\
\hline Plot in a farmland & $5.37 \pm 0.005^{\mathrm{B}}$ & $4.76 \pm 0.008$ & $6.8 \pm 0.010$ & $0.03 \pm 0.002$ \\
\hline \multicolumn{5}{|l|}{ Depths (cm) } \\
\hline $0-15$ & $5.88 \pm 0.003$ & $5.05 \pm 0.005$ & $13.2 \pm 0.006^{\mathrm{A}}$ & $0.10 \pm 0.001$ \\
\hline $15-30$ & $6.02 \pm 0.003$ & $5.04 \pm 0.005$ & $6.2 \pm 0.006^{\mathrm{B}}$ & $0.04 \pm 0.009$ \\
\hline $30-45$ & $5.67 \pm 0.005$ & $4.79 \pm 0.007$ & $5.1 \pm 0.009^{B}$ & $0.04 \pm 0.001$ \\
\hline
\end{tabular}

Means with the same superscripts along the vertical columns are not significantly different at $0.05 \%$ level.

Table 4. Exchangeable cations of the soils of the Inselbergs and their environs ( $\left.\mathrm{cmol} 10 \mathrm{~kg}^{-1}\right)$.

\begin{tabular}{lcccc}
\hline Treatments & $\begin{array}{c}\text { Calcium } \\
\text { Mean } \pm \text { SE }\end{array}$ & $\begin{array}{c}\text { Magnesium } \\
\text { Mean } \pm \text { SE }\end{array}$ & $\begin{array}{c}\text { Potassium } \\
\text { Mean } \pm \text { SE }\end{array}$ & $\begin{array}{c}\text { Sodium } \\
\text { Mean } \pm \text { SE }\end{array}$ \\
\hline Bulk soil & & & & \\
Plot on windward side & $5.03 \pm 0.030$ & $3.10 \pm 0.010$ & $0.25 \pm 0.001$ & $0.46 \pm 0.001$ \\
Plot on leeward side & $3.32 \pm 0.030$ & $2.39 \pm 0.010$ & $0.23 \pm 0.001$ & $0.38 \pm 0.001$ \\
Plot on the main rock outcrop & $2.29 \pm 0.040$ & $2.32 \pm 0.020$ & $0.21 \pm 0.002$ & $0.41 \pm 0.002$ \\
Plot in a cultivated farmland & $2.294 \pm 0.050$ & $2.30 \pm 0.020$ & $0.19 \pm 0.002$ & $0.36 \pm 0.002$ \\
& & & & \\
Depths (cm) & & & & \\
$0-15$ & $4.57 \pm 0.030$ & $2.55 \pm 0.010^{\mathrm{AB}}$ & $0.25 \pm 0.001$ & $0.42 \pm 0.001$ \\
$15-30$ & $2.76 \pm 0.030$ & $2.33 \pm 0.010^{\mathrm{B}}$ & $0.20 \pm 0.001$ & $0.42 \pm 0.001$ \\
$30-45$ & $4.23 \pm 0.040$ & $3.65 \pm 0.020^{\mathrm{A}}$ & $0.24 \pm 0.002$ & $0.39 \pm 0.002$ \\
\hline
\end{tabular}

Means with the same superscripts along the vertical columns are not significantly different at $0.05 \%$ level.

Table 5. Sodium absorption ratio, exchangeable sodium percentage and exchange acidity of the soil.

\begin{tabular}{|c|c|c|c|}
\hline Treatments & $\begin{array}{c}\text { Sodium absorption ratio } \\
\text { (SAR) } \\
\text { Mean } \pm \text { SE }\end{array}$ & $\begin{array}{c}\text { Exchangeable sodium percentage } \\
\text { (ESP) (\%) } \\
\text { Mean } \pm \text { SE }\end{array}$ & $\begin{array}{c}\text { Exchange acidity } \mathrm{Al}^{3+}+\mathrm{H}^{+} \\
\left.(\mathrm{cmolkg})^{-1}\right) \\
\text { Mean } \pm \mathrm{SE}\end{array}$ \\
\hline \multicolumn{4}{|l|}{ Bulk soil } \\
\hline Windward side (plot 1) & $0.25 \pm 0.001$ & $11.33 \pm 0.090$ & $0.06 \pm 0.000$ \\
\hline Leeward side (plot 2) & $0.24 \pm 0.001$ & $6.81 \pm 0.110$ & $0.07 \pm 0.001$ \\
\hline Rock outcrop (plot 3) & $0.27 \pm 0.002$ & $7.93 \pm 0.140$ & $0.08 \pm 0.001$ \\
\hline Cultivated land (plot 4) & $0.02 \pm 0.002$ & $6.33 \pm 0.160$ & $0.06 \pm 0.001$ \\
\hline \multicolumn{4}{|l|}{ Depths (cm) } \\
\hline $0-15$ & $0.25 \pm 0.001$ & $6.25 \pm 0.009$ & $0.06 \pm 0.000$ \\
\hline $15-30$ & $0.27 \pm 0.001$ & $7.59 \pm 0.009$ & $0.08 \pm 0.000$ \\
\hline $30-45$ & $0.21 \pm 0.002$ & $9.21 \pm 0.140$ & $0.05 \pm 0.001$ \\
\hline
\end{tabular}




\section{Soil organic carbon contents and cation exchange capacity}

The distribution of the soil organic matter shows that location of sampling has no significant effect on its distribution. However, the soil organic matter content was medium in status at the leeward side while, in all the other location, the soil organic matter was low. Medium soil organic content recorded at the top $(0$ to $15 \mathrm{~cm})$ soil was expected because organic debris accumulates at the top of the soil before they are decomposed 'in-situ'. Hence top soils usually have a high soil organic matter content. This could also be associated with land use type (Fagawalawa et al., 2014).

Calcium and Magnesium ions were high in plot 1 but medium in the other three plots. Magnesium was seen to increase significantly with depths; this was probably due to leaching, since the study site is usually water log at the peak of the rainy season. High Sodium in all the four plots and in all the depths may be due to chemical fertilizers used on the cultivated plot and nearby farms which is washed off and deposited on the study site. High Sodium can result in soil dispersion, exposing them to erosion. Odunze et al. (2004) reported that the soils of the Northern Guinea savanna have low total nitrogen, organic carbon, available phosphorus and cation exchange capacity. Soil with these characteristics are said to have poor fertility status and very low buffering capacity.

\section{Soil sodicity/alkalinity}

Sodium Absorption Ratio and the Exchangeable Sodium Percentage (ESP) values which are measures of soil sodicity showed that soils at the sampling site were nonsodic/alkaline $(<15 \%)$. The same observation was made for the soil in all the depths. Exchangeable Sodium percentage $>15 \%$ will lead to soil dispersion which will in turn result in poor water infiltration rate and sodium toxicity to plants. Soil sodicity occurs naturally and can be increased by human activities such as irrigation. It is caused by the presence of sodium attached to clay in the soil. It only becomes a problem when there is sufficient sodium attached to the clay to affects soil structure. This low sodicity recorded at the Dumbi inselbergs and its surrounding may probably be due to absence of farming in plots 1,2 and 3 which implies that chemical fertilizer which is one of the causes of alkalinity in soil was low in these three plots when compare with the cultivated plot. The waterlogged nature of the soil could also result in leaching of the inorganic fertilizers, leading to low sodicity.

\section{Soil particle size and soil textural class}

Clay contents in the windward plot differed significantly with the leeward, rock outcrop and the cultivated plot. Surface run-off and wind probably must have deposited clay particles at the windward site. The increased of clay contents with depth at the windward could cause infiltration and percolation problems, hence waterlogging at the peak of the rains. Odunze et al. (1996) also observed increased of clay contents with depth and concluded that increase in subsoil clays could cause impaired drainage at such shallow depths, especially at the peak of the rainy seasons.

Silt contents in plots 1,2 and 3 were significantly higher than that of plot 4 (farmed area). The main rock outcrop slopes towards the windward plot. During the process of soil formation, disintegrated rock particles from the rock are first deposited as sand which later will disintegrate to silt and finally to clay. The weathered rock particles are washed down to plots 1,2 and 3 . The clay particles are leached in to the sub-soil followed by the silt and sand particles accumulate at the top soil. The sand particles are easily washed by rain water depositing them at the farmed area hence, the possible reason for high sand contents at the farm plot and higher silt in plots 1 and 2 . The high silt values observed in plots 1,2 and 3 may account for soil crusting observed in these three plots.

The surface soils were dominantly sandy and had sandy loam in texture. Odunze (2003) who studied the soils of Northern Guinea savanna obtained a similar result and said that such a soil has low soil moisture retention capacity and encourage leaching of nutrients away from the rooting depth of most crops as the root zone of most crops penetrates to a little less than $50 \mathrm{~cm}$. The soils become degraded probably due to effects of soil erosion, overgrazing, nutrients mining and poor soil management strategies adopted by farmers.

The study has revealed some important aspects of the ecology of inselbergs to another level. The major factor identified was anthropogenic activities, such as farming and overgrazing. The soil characteristics of the study site revealed the nutrients level to be lower than what is expected of forest outlier often associated with inselbergs' habitat, rather it corresponds with other soils of the Savanna woodland and can only support crops that grow in poor nutrients soil. This study will form a baseline for further studies on inselbergs.

With these, the following recommendations are made; Completely protected inselbergs should be set aside for in-situ conservation of their biodiversity. Rural communities should be encouraged to establish and own plantations for fuelwood and other wood products. The three tiers of government and NGO's can design a way of assessing and compensating communities or individuals that embark on such projects to encourage participation.

\section{REFERENCES}

Agbenin JO, 1995. Laboratory for soil and plant analysis (selected methods and data analysis). $140 \mathrm{pp}$. 
Anderson JM, Ingram JIS, 1993. Tropical Soil Biology and Fertility: A Handbook of Methods. $2^{\text {nd }}$ ed. C. A. B. International Wallingford, U.K. $221 \mathrm{pp}$.

Bates RC, 1954. Electrometric Ph determination. John Wiley and Sons Inco. New York pp: 35-38.

Blake GR, 1965. Bulk Density in: Black C.A., D. D. Evans, J. L. White, L.E. Ensmine and F.E. Clark (eds) Methods of Soil Analysis Part 1. Physical and Mineralogical Properties, including Statistics of Measurement and Samples. Am Soc Agron, 9: 604-613.

Chapman HD, 1965. Cation exchange capacity. In: methods of soil analysis (Black C. A. ed) part 2 No. 9 in the series Agronomy. American Institute of Agronomy, Madison Wisconsin 891-901.

Day PR, 1965. Particle Fractionation and Particle-size Analysis. In: C. A. Black, D. D. Evans, J. L. White, L. E. Ensminger and P. E. Clark (eds). Methods of Soil Analysis, part 1, American Society of Agronomy, Madison, Wisconsin, U.S.A. pp: 545-567.

Fagwalawa LD, Abdullahi SM, Yakasai MT, Fadimu OY, 2014. Physicochemical composition of soil collected from different habitats within Bayero Univerity, Kano, Nigeria. Biol Environ Sci J Trop, 11(1): 2123.

Feller C, Balesdent J, Niclardot B, Cerri C, 2001. Approaching Function Soil Organic Matter Pools through Particle Size Fractionation. Examples for Tropical Soils. In: Lai, R., Kimble, K. M. and Tollet, R. M. (eds). Assessment Methods for Soil Carbon. Advances in soil science, CRC Press Boca Raton, USA, pp 53-57.

Ganry F, Feller C, Harmand J, Guibert H, 2001. Management of soil organic matter in semi-arid Africa for annual cropping, nutrients cycling in agroecosystem. System, 61: 105-113.

Gee GW, Bauder JW, 1986. Particle Size Analysis. Methods of Soil Analysis. Part 1. Physical and Mineralogical methods, $2^{\text {nd }}$ edn., American Society of Agronomy. Madison, WI. pp 383-411.

ILRI, 1997. Livestock, People and Environment. International Livestock Research Institute, Addis Ababa, Ethiopia, $61 \mathrm{pp}$.

Iwuafor ENO, Yusuf AA, Olufajo OO, Abaida R, Saginga N, 2006. Residual benefits of two cowpeagenotype and natural fallow to subsequent maize in the northern guinea savanna of Nigeria. $18^{\text {th }}$ world congress of soil science, July 9-15, 2006, Philadelphia Pennsylvania USA.

Jackson RM, Rowa F, 1996. Life in the Soil. Academic university Press, p 26.

Jenkinson DS, Adams DE, Wild A, 1991. Model estimates of $\mathrm{Co}_{2}$ emissions from soil in response to global warming. Nature, 351:304306.

Johnson DW, 1992. Effects of forest management on soil carbon storage. Water Air Soil Pollut, 64: 83-120.

Longtau S, Odunze AC, Ahmed B, 2002. Case Study of Soil and Water Conservation in Nigeria. Field Study Reports. In: Rethinking Natural Resource Degradation in Sub-Saharan Africa: Policies to Support Sustainable Soil Fertility Management, Soil and Water Conservation among Resource-Poor Farmers in Semi-arid Areas. Tom Slaymaker Roger Blench (eds). Overseas Development Institute (UK) and University for Development studies, Tamale, Ghana. Vol11: chapter 111: $1-41$

Nelson DW, Sommers LE, 1982. Total C, organic C and organic matter. Methods of soil analysis 2, chemical and microbiological properties. Agronomy, 9: 539-579.

Odunze AC, 2003. Effect of forage legumes incorporation on selected soil properties in the Northern Guinea savanna of Nigeria. J Sustain Agric, 22(1): 11-112.

Odunze AC, Tarawali G, Magaji SO, 1996. Nigerian subhumid savanna zone Alfisols for sustainable crop and livestock production. Arid Soil Res Rehab, 10: 256-276.
Odunze AC, Tarawali SA, De Haan NC, Iwuafor ENO, Katung PD, Akoueguon GE, Amadji F, Schultze-Kraft R, Atala TK, Ahmed B, Adamu A, Babalola AO, Ogunwale JO, Alimi A, Ewansiha SU, Adediran SA, 2004. Grain legumes for soil productivity improvement in the Northern Guinea savanna of Nigeria. Food Agric Environ, 2(2):218-226.

Oster JD, Sposito G, 1980. The Gapon coefficient and the exchangeable sodium percentage- sodium asorption ratio relation. Soil Sci Soc Am J, 44(2): 258-260.

SAS Statistical Package, 2011. SAS mixed model. SAS Institute.

Six J, Conant RT, Paul EA, Paustian K, 2002. Stabilization mechanisms of soil organic matter. implications for $\mathrm{C}$-saturation of soils. Plant and Soil, 241: 155-176.

Smart, Growing Intelligent, 2012. Soil Chemical Analysis as a tool for evaluating nutrient availability. Available at www.smartfertilizer.com/articles/soil-chemical-analysis, accessed on 23/06/2018.

Tanko D, 2012. Some Aspects of Ecology of the Dumbi Inslebergs and its surrounding environment. Unpublished $\mathrm{PhD}$ Dissertation, Department of Biological Sciences, Ahmadu Bello University, Zaria, Nigeria, $196 \mathrm{pp}$.

USDA.NRCS, 1992. Soil Survey Laboratory Methods Manual. Soil Survey Investigation Report No. 42, National Soil Survey Center, Lincoln, NE.

USDA, 1975. Soil Taxonomy. A basic system of soil classification for making and interpreting soil surveys. Washington D.C. 745 pp.

Uwah DF, Ogar CC, Effa EB, 2012. Response of sweet maize (Zea mays L. Saccarata) to poultry manure and row spacing in Uyo, Akwa Ibom state, Nigeria. In: M. G. Solomon, A. Egrinya-Eneji, N. M. John, D. A. Ukeh and P. B. Okon (eds). Organic agriculture and and National Development. Proceedings of the $8^{\text {th }}$ Annual Conference of organic agriculture project in tertiary institutions in Nigeria p-15.

Citation: Tanko D, 2018. Physical and chemical composition of soil collected from different habitats of Dumbi Inselberg in Zaria, Northern Guinea savanna, Nigeria. Net J Agric Sci, 6(3): 35-41. 